\title{
学びを促すポートフォリオ評価一一実践報告 Empowering the Learner through Portfolio Assessment
}

\author{
村田美子 （関西外国語大学）
}

\begin{abstract}
要旨
Content-basedや、学習者中心型授業でプロジェクト・ワーク等に学生が取り組んだ場合 など、その評価段階で社会文化能力、批判的思考力、問題解決能力等、従来の項目別客観 テストでは計りきれない力を評価する代替的方法が求められる。ここでは評価の概念、言 語学習観、教授観、学生と教師の力関係などを根本から捉えなおし多肢選択問題から脱却 したよりインターラクティブで、個を反映したポートフォリオに焦点を当てる。ポートフ オリオはある期間中の学習者の作品、体験、自己評価、などを系統的に集めたもので学習 者の目標、それに向けての努力、成長、プロセス、結果、今後の方向性などを知ることが できるデータである。筆者が担当する教授法、Critical Thinking Skills、アメリカ社会 （DVに焦点を当てる）のクラスで試みたポートフォリオ及び、その評価法を紹介し、学生 の反忘、今後の課題等を議論した。

学生にインタービュー、アンケートを行った結果、学生達の大半はポートフォィオを肯定 的に捉え、やる気や自信、対話の向上、学び方の会得などをあげていた。本稿では教師の負 担を軽堿できるよう周到な計画手順をあげ、又妥当性、信頼性の問題を减少すべく、明確な 評価基淮、複数の採点者等のヒントをあげた。今後、自己評価のあり方について、また電子 化についても研究をすすめたい。
\end{abstract}

\section{Summary}

When students are involved in student-centered language learning activities such as group projects or when the instruction is content-based, it is difficult for teachers to evaluate the student performance using only traditional multiple- choice examinations. Alternative assessment is needed to evaluate student socio-cultural competence, critical thinking skills, and problem solving skills. This paper examines and rethinks the concept of evaluation, how to learn and teach languages, and the power relations that exist between teachers and students. It pays particular attention to portfolio assessment.

A portfolio is a systematic self-collection of student work, including self-evaluations and reflections on certain periods during learning activities. Portfolio assessment is the data for both the student and the teacher to show or catalog the student' $s$ efforts, progress and future directions as well as the summative results of routine class activities.

In a survey conducted in three college-level classes, students had a positive reaction towards portfolio assessment as a means of developing student intrinsic motivation, fulfillment, self-esteem, and social interaction among peers.

The paper offers some advice on how to overcome the difficulties of the portfolio assessment, including developing relevant criteria and designing a score sheet. 


\section{1. はじめに}

2001 年、大阪にある私立大学の 3 クラスにおいてポートフォリオ評価の導入を試みた。 その理由は年々低くなる入学者の学力、意欲、さらに $4 \sim 5$ 割の学生が家庭学習 1 時間以下とい う現状の中で、学生たちの関心を学びに向け、彼らの自主性を伸ばすには評価の概念、言語学習 観、教授観、学生と教師の力関係などを根本から捉えなおす必要性を感じたからである。多肢選 択問題から脱却した代替評価法であるポートフォリオ評価の実践を報告し、今後の課題について も提示する。

\section{2. 理念}

限られた時間内に多くの項目を回答していく従来のテストは、「知性は言語的及び論理・数学 的能力である。」とする I Q 概念に基づくものである。Gardner, H は intelligence（知性）を "the capacity to solve problems or fashion products that are valued in one or more cultural

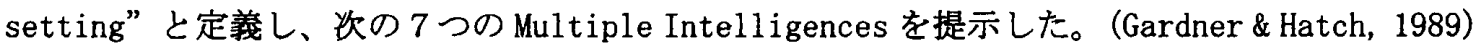
すなわち知性にはLinguistic Intelligence (言語)、Logical-Mathematical Intelligence (論 理・数学)、Spatial Intelligence (問題解決のためのイメージ作り)、Musical Intelligence (音 楽)、Bodily-Kinesthetic Intelligence（運動)、Personal Intelligence (自己管理、対人関俰)、

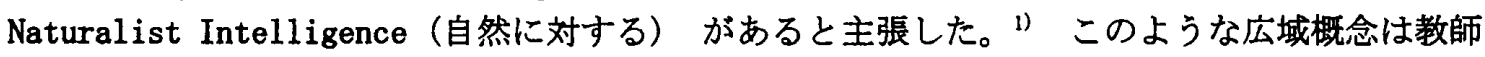
を学習者中心型授業形態や代替的評価へと意識の変革を促す理論的背景となった。

\section{$2-1$ 代替的評価}

学生の学習の結果としての知識の質と量を教師が点数により評価する伝統的な評価法に対し て、教育、習得のプロセスと評価を統合する形の formative assessment（形成的評価）に焦点 を当てた代替的評価法が英米の教育界で広く使われるようになってきている。これは従来のよう に点数により順位をつけ、競争によって学力を伸ばすのではなく、個々のニーズに合った教育を 行おうとする英米の教育の方向性に合致する。代替的評価方法にはポートフォリオ、カンファレ ンス、ジャーナル、スタディー・ログ、リフレクション、自己評価、仲間による評価、観察等が ある。学習者自身が学習プロセスの評価に参加することにより学習者の自律学習を促す、学習者 参加型評価方法である。

2-2 ポートフォリオ、及び、ポートフォリオ評価

portfolio（ポートフォリオ）とは、もともと書類入れやファイルを意味する。ポートフォリオ は「ある期間中の学習者の作品、体験、自己評価、などを系統的に集めたもので、学習者の目 標、それに向けての努力、成長、プロセス、結果、今後の方向性などを知ることができるデー タである。そのデータを使って評価する学習者と教師の共同作業がポートフォリオ評価である。

ポートフォリオの特徵、及び、その意義をあげる。

1）教育・学習の結果のみならず、その過程、目標、教室外での学習、成長も評価の対象 としている。そのため、ある期間中にやり遂げた「自分の作品」であるといった「過 程」(process）の感覚を育てることができ、過程で獾得した知識を次に活用できると いう認識や力を学生に与えることができる。 
2）評価に教師だけでなく学生も参加する共同作業である。そのため学生の学習意欲や自 己の学習に対する责任感、自発性の向上が期待できる。教師と学生が次の目標を決定 したり設けたりすることができ、学生の self-esteem(自尊感情)を高める。

3）唯一の正解を求めない。open-ended question すなわち、いろいろな答を董する。 そのため学生の思考力を養う機会が增える。

4）現行のカリキュラムに部分的に利用可能である。

Hancock（1994）は学習者がポートフォリオを通じて自らの学習に積極的に意欲的に関わりだ す理由を次のように述べている。

ポートフォリオは学習者に質の高い活動とは何かという基淮を明らかに示すので、学習 者はその基準に近づこと努力し、やがてはその勢を自分のものとする。また、他の 人とも共有する価値があり、後になっても何度も振りかえることの出来る作品を最終的 に生み出すので、意味のある活動に学習者が取り組むことができる。また、ポートフォ リオの活動を通じて学習者は教師と双方向のコミュニケーションという新しいチャン ネルを得ることが出来る。このように、ポートフォリオの究極の利点は学習者が自分の 自発性を最大限に発揮できる点である。(4)

しかしながら以下にあげるような困難点も伴う。その克服法も提案してみる。

1）評価に時間がかかる点。その負担を怪诚する為、周到な準備と綿密なCriteria (評価基準)を設ける必要がある。Appendix 1 参照。

2）評価者の主観が入りやすい点があげられる。Validity （妥当性）Reliability （信頼性）の問題を解決するため、評価者を褀数にするなどの工夫がいる。 Appendix 2 参照。

3）学習者が多い場合実施が困難である。ポートフォリオの電子化の試みで克 服可能か?

\section{3. 自律への湖きかけの実践}

筆者が担当する「アメリカ社会」( 30 名の短大生が受绕した)、Critical Thinking Skills (学部 2 年生 10 名)、日本語教授法（学部 $3 、 4$ 年生 30 名）、のクラスで試みたポートフォリ オ評価を紹介し、学生の反応、reflection（内省）、peer-evaluation（仲間による評価）、 self-evaluation (自己評価)、conference (面談)、今後の課題等を議論したい。担当のクラス のうち American Society と Critical Thinking Skills は Content-based で、前者は 
Domestic Violenceに焦点をあて、Mary Susan Miller 著 “No Visible Wounds”（1 9995 年 Fawcett）をテキストとして使用した。Critical Thinking Skills のクラスでは日常の思考 の見直し、問題解決能力、批判的思考能力、理性的思考能力開発、自己中心的思考の改善などを 目標にし、クラス内外でタスク活動に取り組んだ。使用したテキストは Richard Paul 、Linda Elder 著" Critical Thinking- Tools for Taking Charge of Your Learning and Your Life" (2 000 年 Prentice Ha11）である。教授法のクラスは学習者中心型授業で、タスク作業やプロジ エクト・ワークに取り組んだ。日本語教育学会編「タスク日本語教授法」（1990年 凡 人社）をテキストとした。どのクラス共、学期の終わりには自分の選んだテーマでプレゼンテー ションし、クラス討論をした後で最終レポートを提出した。いずれも 90 分週 2 回の授業である。

まず、1 学期（1 5 週）の流れを明確にしよう。

表 1

\begin{tabular}{|c|c|}
\hline 第 1 週 & $\begin{array}{l}\text { シラバス配布。自己紹介、自己診断表の記入。ポートフォリオ、及びポートフォ } \\
\text { リオ・アセスメントについての説明。評価全体の合意 (Appendix 1)、スコア } \\
\begin{array}{lll}\text { シート(Appendix } & \text { 2) スタディー・ログ (Appendix 3) }\end{array}\end{array}$ \\
\hline 第 5 週 & スタディー・ログの中間提出と中間 Self-Evaluation 1 (Appendix 4) \\
\hline $\begin{array}{l}\text { 第 } 6 \text { 週〜 } \\
\text { 第 } 10 \text { 週 }\end{array}$ & $\begin{array}{l}\text { レポートのテーマを各自選択。授業と平行して、クラス外でテーマを深める。 } \\
\text { 希望者に面談。 }\end{array}$ \\
\hline 第 14 週 & プレゼンテーション、 peer-evaluation \\
\hline 第 15 週 & $\begin{array}{l}\text { レポート提出、ポートフォリオに関するアンケート } \\
\text { (Appendix 5) }\end{array}$ \\
\hline
\end{tabular}

\section{4. 結果と考棎}

学期の終わりにアンケートを 3 クラスで実施した。表 $2 \sim 3$ がその結果である。(回収率は 8 $4 \%$ \%でった。)

表 2

\begin{tabular}{|c|c|}
\hline 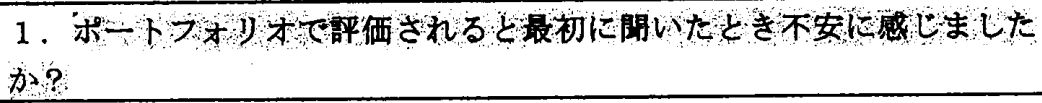 & $\begin{array}{l}\text { 38\%の学生が不安に感じ } \\
\text { た。 }\end{array}$ \\
\hline 2. 学期閒終丁の今 ホートフォリォ形式は好きでか? & 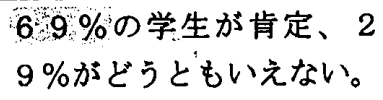 \\
\hline 3.担当者からのポートフォリオ、およびその評価の説明は充分でしたか? & $83 \%$ 学生が充分。 \\
\hline
\end{tabular}




\begin{tabular}{|c|c|}
\hline 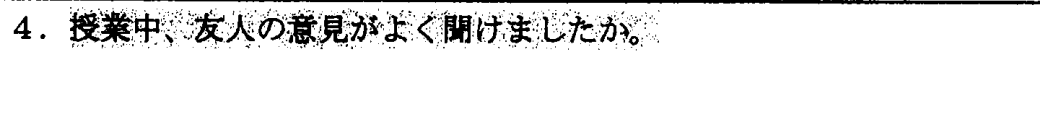 & $\begin{array}{l}90 \% \text { 学生がよく闒け } \\
\text { た。 }\end{array}$ \\
\hline 5. クイズや定期考查がなかったので精神的に楽でしたか? & $\begin{array}{l}73 \% \text { 学生が精神的に楽 } \\
\text { だった。 }\end{array}$ \\
\hline 6. 上記がなかったのでメリハリがなく退届でしたか? & $\begin{array}{l}85 \% \text { 学生が退屈ではな } \\
\text { かった。 }\end{array}$ \\
\hline 7. 日常の宿題が多かったのですが、できましたか? & $69 \%$ 6 できた。 \\
\hline 8. 学期途中の自己評価は意欲を高める点で役に立ちましたか? & 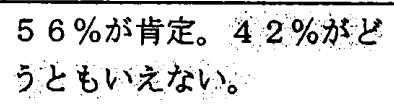 \\
\hline 9.プレゼンテーションは㴶備よくできましたか? & $67 \%$ \%゙できた。 \\
\hline 1 0.最終レポートはよくがんばりましたか? & $\begin{array}{l}85 \% \text { 学生ががんばっ } \\
\text { た。 }\end{array}$ \\
\hline 11 . 学習ログは日々の予習や宿題、レポート作成に励みになりましたか？ & $69 \%$ 励みになった。 \\
\hline 12 . 今後のクラスにもポートフォリオを薦めますか? & $88 \%$ 学生が蓭めたい。 \\
\hline 1 3. ポートフォリオは学習意欲を高めるのに役立ったと思いますか? & $77 \%$ 学生が肯定。 \\
\hline 14. 授業で出さきたしとを友人や家族と話題にしたことがありますか? & $94 \%$ 話題にした。 \\
\hline $\begin{array}{l}\text { 15. 他の科目と比較してポートフォリオ形式の授業では家庭学習の時間 } \\
\text { に変化がありましたか? }\end{array}$ & $\begin{array}{l}\text { 長くなった - } 65 \% \\
\text { 変わらないー- } 29 \% \\
\text { 短くなったー } 6 \%\end{array}$ \\
\hline 16.900分の授業に対し大体何分ぐらい勉强しましたか? & $\begin{array}{ll}3 \text { クラス平均 } & \\
1 \text { 時間以下 } & 14 \% \\
1 \text { 時間 } & 20 \% \\
2 \text { 時間 } & 47 \% \\
3 \text { 時間 } & 10 \% \\
3 \text { 時閒以上 } & \quad 20 \%\end{array}$ \\
\hline
\end{tabular}

アンケートの結果、学期の初め、疑心暗鬼だった学生も次第にポートフォリオに慣れていった こと、学生の多くは学生同士の、また教師との双方向のコミュニケーションに大きな価值と喜び をおいていること、家庭学習時間が格段に伸びたこと等が明らかになった。家庭学習時間ついて は長ければよい、というものではなく学習への真剣な取り組みのひとつの目安としたい。授業で 出てきたことをクラス外でも話題にした学生が多かった。学期途中の自己評価と学習意欲向上に関 して4 $2 \%$ 学生が「どうともいえない。」：表明している．今後、自己評価のあり方の改善が 必要である。 


\section{質的調查}

\begin{tabular}{|c|c|}
\hline ポートフォリオに関して良かった点 & 嫌だった点 \\
\hline 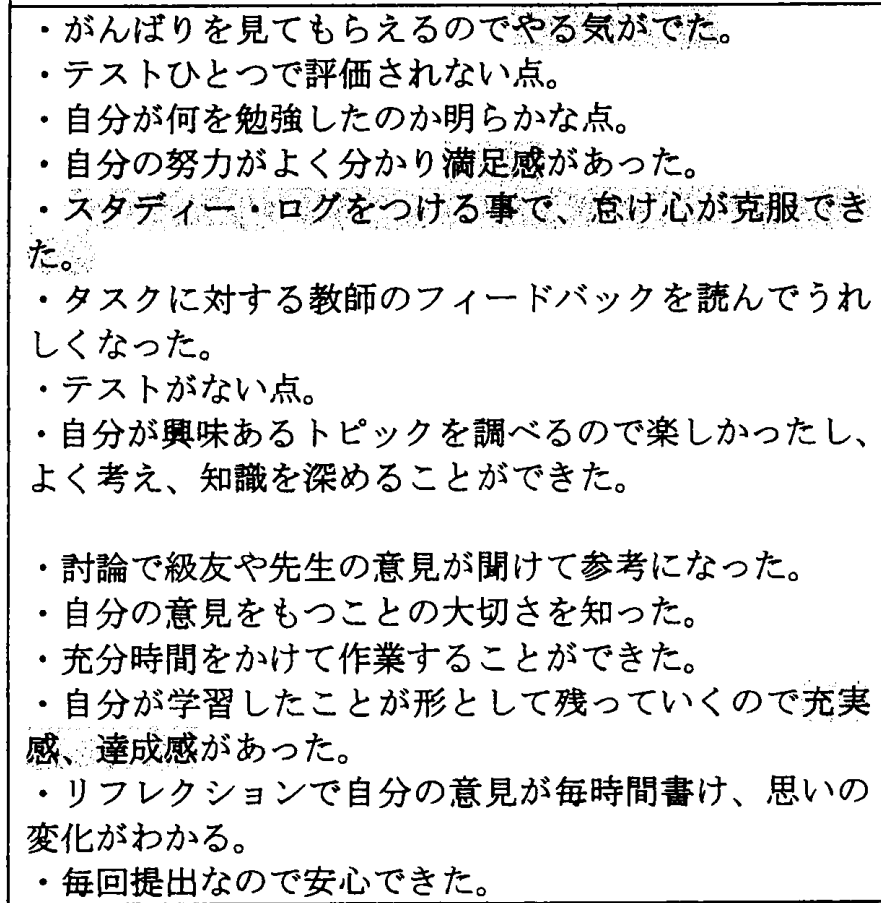 & 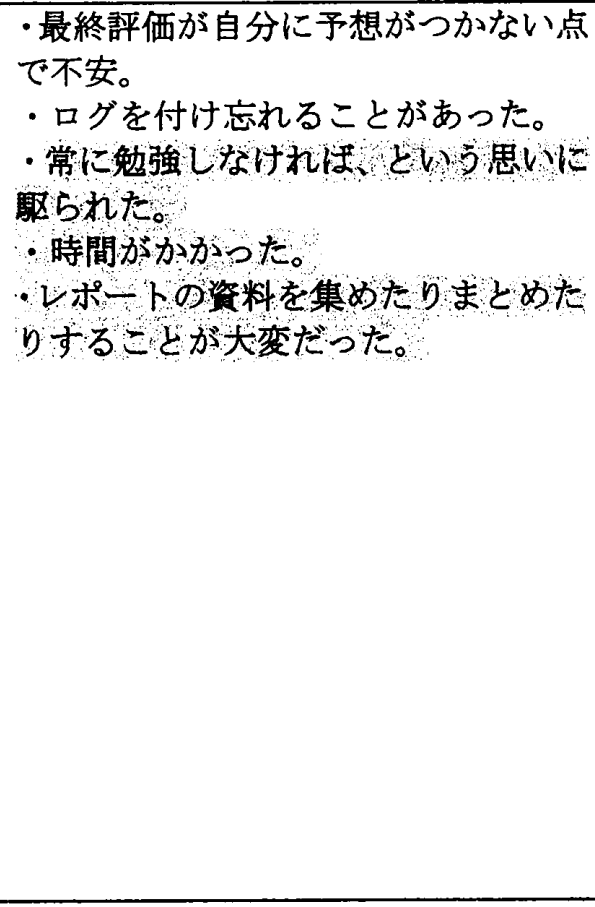 \\
\hline
\end{tabular}

ポートフォリオに関して良かった点であげられた意見から学生は友人や教師とのインターア クションを望んでいること、学ぶ喜びをみいだしていること、リフレクションから自分の成長を 感じ取っていることなどが明らかになった。嫌だった点にあげられた最初の二つ以外は、学び方 を学んで欲しいと願う教師にとっては否定的な回答では決してない。ログをつけることに負担 を感じた学生もいたが、学習時間に関しては教師の側から増やすよう圧力をかけたことはなく、 むしろ量よりも質が大切なことは明白である。また「次に到達したい目標は何ですか？」と言う 問いに対し、「原書を読むのは始めての体験で自分にも読める、という自信に獒がった、自分で も他の原書を読んでみたい。」(American Society)「学んだことを使って、これからの考え方や 人間関係をよくする。(Critical Thinking Skills) 「知識が深まったので今度は自分の意見を 言えるようにしたい。困難はあるけれど絶対日本語教師になる、と決心した。」（日本語教育法） 等、の意見が闒けた。

\section{5.まとめと今後の課面}

大学生を対象に言語教育分野でのポートフォリオ活動とその評価について述べてきた。代替的 評価が求められるいろいろな分野でも応用が可能である。「学生、教師の発想の転換小「自己評 価」、明確な評価基準」がキーになることを強調したい。学生は自分の進歩をモニターし、目標 に近つく責任を教師と共に味わう、といったことは学生にとって初めての機会だったかも知れな い。確かに客観テストに比べて教師の負担は格段に増える。しかし学生が意欲的に家庭学習に取 り組み、クラス活動においても前向きの姿势を見せてくれることは何物にも変えられない教師の 喜びである。また今回はかなり難解な authentic materials（生の教材）を使用したが、学生達 は多少の困難はあったものの挑戦した。教師の側で決して expectation（生徒への期待）を低め て選択してはいけないことを再認識した。 
以上、本稿では教師の負担を軽減できるよう周到な計画手順をあげ、又妥当性、信頼性の問題 を減少すべく、明確な評価基準、襍数の採点者等のヒントをあげた。参考になれば幸いである。 今後、ポートフォリオ・アセスメントが学習者の自信、自尊感情にどのような影㗽を与えるか、 自己評価のあり方について、また電子化についても研究をすすめたい。最後に以下のまとめをし て本稿を終わりにする。

1）主観的評価が有効性を持つには学生と教師の信頼しあう土壤が必要である。

2）知識の内面化のためにリフレクションが重要な役割を持つ。

3）Learn how to learn すなわち学び方を考える時間を持つことが大切である。教室という箱 の中だけで教育が成立するのではないことを教師、学生ともに認識する。

4）学び方を模索している学生にとってポートフォィオ・アセスメントが勃果をもつことがわか った。従来の評価法に付け加えるかたちでの応用を蔍めたい。

注

1) Gardner, H. \& Hatch, T. (1989). Multiple intelligences go to school: Educational implications of the theory of multiple intelligences. Educational Researcher, $18(8), 4-9$

2) Wolf, D. P. (1989). Portfolio assessment: Sampling student work. Educational Leadership, $46(7), \quad 35-39$

3) Tierney, R. J. , Carter, M. A. , \& Desai, L. E. (1991). Portfolio assessment in the reading-writing classroom. Norwood, MA: Christopher-Gordon Publishers.

4) Hancock, C. R. (ED.). (1994). Teacher, testing, and assessment: Making the connection. Northeast Conference Report. Lincolnwood, IL: National Textbook Co. 


\section{主要参考文献}

Brualdi, Amy C. (1996). Multiple intelligences: Gardner's theory. Practical Assessment, Research \& Evaluation, 5(10).

エスメ・グロワート著／鈴木秀幸訳『教師と子どものポートフォリオ評価』論創社, 1999 年, p. 9

Gardner, H. (1983). Frames of Mind. New York: Basic Books Inc.

Gardner, H. (1987, May). Developing the spectrum of human intelligence. Harvard Educational Review, 76-82.

Gardner, H. (1991). The unschooled mind: how children think and how schools should teach. New York: Basic Books Inc.

Gardner, H. (1993). Multiple Intelligences: The theory in practice. New York: Basic Books.

Gardner, H. (2000). Intelligence Reframed: Multiple Intelligences for the 21st Century. New York: Basic Books Inc.

小田勝己『総合的な学習に適したポートフォリオ学習と評価』学事出版, 1999 年, pp. 20-21 當作靖彦 （2000）「アメリカの外国語教育における評価の動向一代替的評価を中心として一」 『平成 11 年度日本語教育学会秋季大会』 シンポジュウム資料

Miggins, G. (May 1989). A true test: Toward more authentic and equitable assessment. Phi Delta Kappan, 70, 703-713.

Wiggins, G. 1990. The case for authentic assessment. ERIC Digest. Washington, DC: ERIC. (ED328611)

Wolf, D. , Bixby, J. , Glenn, J. G. , \& Gardner, H. (1991). To use their minds well: Investigating new forms of student assessment. In G. Grant (Ed. ), Review of research in education (No. 17). Washington, D. C. : American Educational Research Association. 
Appendix 1

$$
\text { ポートフォリオの評価基渞 }
$$

次に皆さんが提出するポートフォリオがどのように評価、点数化されるのか明らかにして おきます。ポートフォリオは成績资料の（４０％) で、クイズ（１０％)、プレゼンテ ーション $(20 \%) 、$ 平常点 $(10 \%) 、$ 最終レポート $(20 \%)$ を総合的に资料とします。 ポートフォリオの採点基準は以下の通りです。着目点はしっかり準備され構成はしっかり しているか、まじめに取り組んだか、創造性に富み質的に良いものか、発音, 文法、語集、 流啺さ、社会文化的言語能力すべてを総合的に判断してわかり易い表現になっているか、 問題分析、問題解決能力、批判的思考能力はあるか、の 5 項目です。それぞれの項目に 0 〜 4の評価をします。私は最後の「問題分析、問題解決能力、批判的思考」は日本の大学生 に是非養ってもらいたい課題だと考えています。

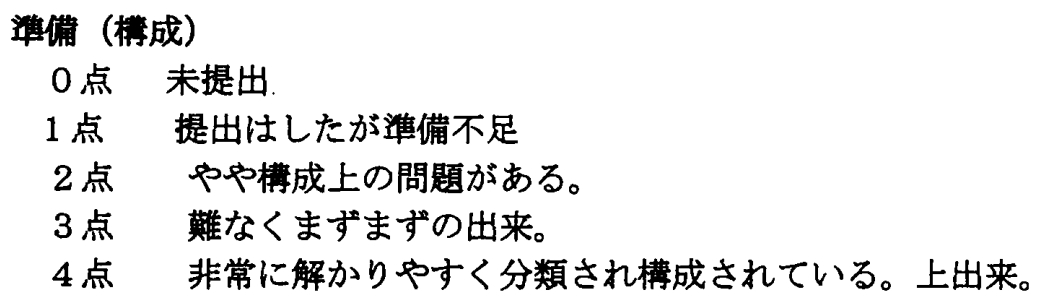

内省 (努力、葲度)

0 点 学習ログ未提出

1 点 内省が出来ていない。

2 点 内省が一般的である。

3 点 思慮深い箇所もあるが提出资料との関係が薄い。

4 点 真擎な態度で懸命に努力した跡がうかがえる。

\section{創造性（而）}

0 点 他人の模做である。

1 点 学習者の力をほとんど反映していない。

2 点 質的に高いと言えない。

3 点 あと 1 歩の創造性が求められるがまずまずの出来。

4 点 非常に創造性に富み良い。

解かり易さ（発音、文法、語整、流䑦さ、社会・文化的言語能力）

0 点 解からない。

1 点 問題が多いがなんとか理解できる。

2 点 時々解からない籄所がある。 
3点 ほとんど解るが不自然な部分が見受けられる。

4 点 非常に自然で解かりやすい。

問題分析、解決能力、批判的思考

0 点 何が問題点か解かっていない

1 点 問題の指摘はなされているものの十分思考されていない。

2 点 問題の分析、解決力がやや弱い。

3 点 問題分析は良く出来ているがやや視野が狭い。現実味に欠ける箇所がある。

4 点 問題とその周辺状況を良く理解し、資料を集め、適切に問題を分析し、解決のための 提案がなされている。

Appendix 2

スコアーシート

ポートフォリオの評価は従来の客钼テストと違いかなり採点者側の主観が入りやすいの で探点者は 2 名います。次のスコアシートを見てください。このクラス (American Society) では、準備 8 点、内省 8 点、創造性 8 点、解かり易さ 8 点、問題分析、解決、批判能力 8 点 計 40 点とします。

採点者 \#1

採点者\# 2

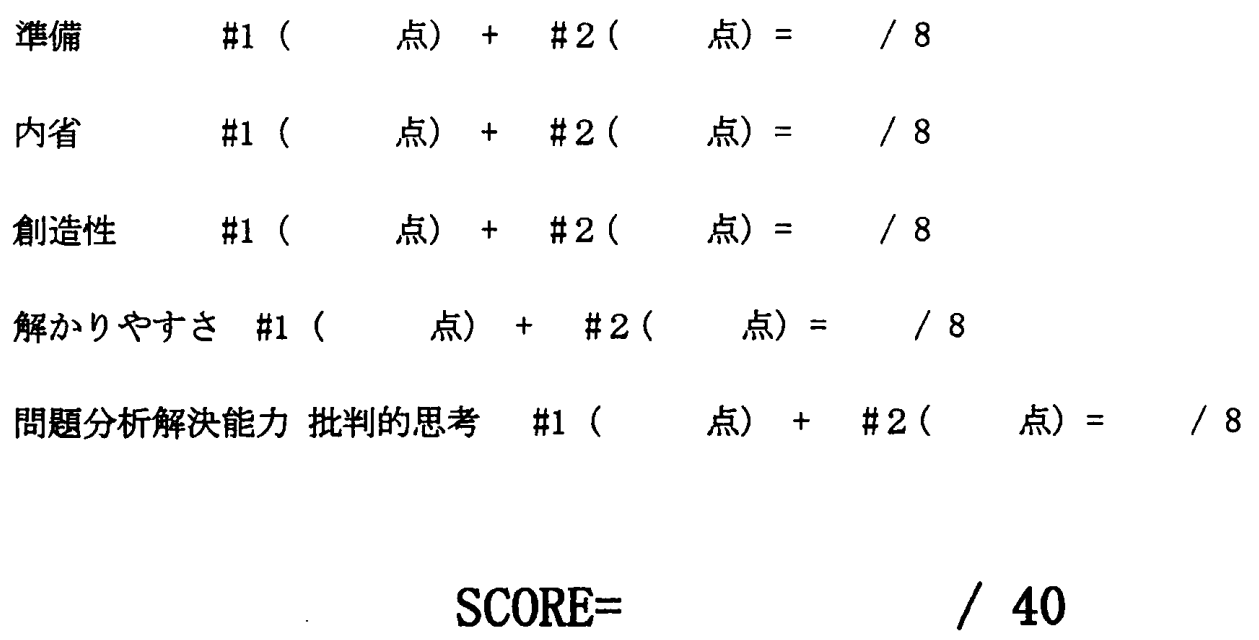




\section{Appendix 3}

\section{$\underline{\text { Study } \log }$}

\begin{tabular}{|l|l|l|}
\hline Date & Time & \\
\hline & & \\
\hline & & \\
\hline & & \\
\hline & & \\
\hline & & \\
\hline & & \\
\hline & & \\
\hline
\end{tabular}

Appendix 4

SELF-EVALUATION 1

1. Study Log は毎回記入していますか? 学習の励みになっていますか?

家庭学習に関しての自分の姿勢を反省してみてください。

2. 授業の進め方に関して要望や建設的な意見があれば記入して下さい。

3. このクラスで自分が目標にすることは何ですか?この 1 ヶ月で少しでもその目標に 近づきましたか?

4. 最終レポートのテーマは決まりましたか?

5.レポートを仕上げるに際し、先生に相談したいことや資料の贷し出し希望はありますか？

Appendix 5

授業に関して

SELF-EVALUATION 2

1 . 知識が深まったと感じますか?

2. 今後の生活に何らかの形で役立つと思いますか?

3. 学期の初めに考えた到達目標に近づけましたか?

$1-2-3-4-5$

$1-2-3-4-5$

$1-2-3-4-5$

4. 自分で評価するとしたらA（100点〜 90 点）、B ( 90 点〜 80 点)、C ( 80 点〜 70 点)、D ( 70 点〜 60 点) のいずれですか。 $A-B-C-D$

5. 次に到達したい目標は何ですか? 